\title{
Introduction: \\ Silence in institutional and intercultural contexts
}

ADAM JAWORSKI

It used to be customary to write about silence beginning with a bit of a lament that it was a 'neglected' or 'undervalued' area of sociolinguistics, discourse analysis and other related disciplines. This is no longer necessary nor possible. Since the publication of the major collection of articles by Tannen and Saville-Troike (1985), a steady stream of monographs and anthologies on silence has continued to bring new titles (e. g., Jaworski 1993, 1997; Kurzon 1997; Cacoullos and Sifianou 1998; Thiesmeyer 2003; Julé 2004; Granger 2004), to mention just a few older and more recent examples. They all examine silence from a range of different approaches, or use the concept itself as a useful metalinguistic category and metaphor for the study of a plethora of communicative forms and functions, and critical social issues (see also, e. g., Huckin 2002; Leander 2002). Final anointment to mainstream status, raising silence from the obscurity of one of the most esoteric researchable topics, is the inclusion of whole sections on 'silence' in standard textbooks in sociolinguistics (e.g., Mesthrie et al. 2000), discourse analysis (e.g., Johnstone 2002), and nonverbal communication (e. g., Guerrero et al. 1999).

Therefore, it came to me as no great surprise that my call for papers a few years back for a Symposium on 'Silence in communication' was met with considerable interest and enthusiasm. The papers gathered in this special issue of Multilingua are revised and expanded versions of some of the contributions prepared for this particular event held as part of the 8th International Conference on Language and Social Psychology (ICLASP 8) at the City University of Hong Kong, Hong Kong, 10-14 
July, 2002 (see also Ng et al. 2004). In this sense, the papers represent a snapshot of recent work on silence rather than a collection of studies responding to a specific methodological or thematic agenda. Yet it is hard not to notice some interesting theoretical and analytic commonalties running through these seemingly disparate contributions, alongside the diversity and richness of data descriptions and interpretations.

All of the papers collected here can be said to examine silence in a range of institutional settings: criminal justice system (Cotterill), ESL classroom (Julé), ante-natal care hospital unit (O Malley), business meetings (Spencer-Oatey and Jianyu Xing), university tutorials (Nakane), ethnographic interviews (Galasiński and Galasińska), and TV broadcast news (Jaworski, Fitzgerald and Constantinou).

Following Levinson's (1992) work on 'activity types' in interaction, Drew and Heritage (1992: 22-25) define institutional talk in terms of three features of participants' orientations to interaction:

1. orientation of at least one participant towards an institutional goal, task or function;

2. formal constraints on the type of contributions which the participants can make, and;

3. distinctive patterns of inferential processes and procedures.

It is probably unsurprising that silence in institutional settings draws researchers' attention as, typically, it is not expected to occur there. Despite their 'right to silence' defendants and suspects are expected to give verbal, truthful and accurate testimony (Cotterill); in classrooms (Julé; Nakane) and business meetings (Spencer-Oatey and Jianyu Xing) discussion is probably thought of as the prototypical activity; likewise, the requirement for the informativeness of medical consultations (O Malley), ethnographic interviews (Galasiński and Galasińska) and broadcast news (Jaworski et al.) proscribes anything but a constant, uninterrupted flow of talk. Yet silence does occur in all of these contexts, which may appear to violate the second definitional feature of institutional talk cited above, which in turn, may question participants' willingness to orient to the stated institutional goals (cf. 1, above). It is these uses of special, unexpected forms that makes them noticeable, then, and in need of description, interpretation and explanation (cf. Drew and Heritage 1992: 12-13).

But the occurrence of silence in the contexts mentioned above is only part of the story. As Drew and Heritage suggest, institutional talk is also characterised by the 'distinctive patterns of inferential processes and procedures', and drawing inferences from silence may, at times, be more problematic than from other linguistic forms. It has been argued that silence is the most indirect and ambiguous form of linguistic communica- 
tion (cf. Tannen 1985), yet capable of expressing a whole range of discursive and propositional meanings, and displaying the same illocutionary effects as verbal speech acts (Saville-Troike 1985). Of course, for researchers, things get interesting when there are observable or implied mismatches in drawing inferences from silence, which is often the case in intercultural communication.

Following Scollon and Wong Scollon (1995) in defining culture as a 'discourse system', we can assume that almost any two persons coming from slightly different social, professional or educational backgrounds, may be representatives of different 'cultures'. Thus when midwives and their clients at the ante-natal clinic (O Malley), academic researchers and their interviewees (Galasiński and Galasińska), police officers, trial judges, defendants and members of the jury (Cotterill) come into contact with one another, we may construe such interactions as instances of intercultural communication, whereby all social actors may differ somewhat in their patterns of expectation as to what constitutes efficient, successful, sincere, etc. communication. Resulting mismatches in the interpretations and uses of silence have often been studied in communication between members of communities broadly sharing a linguistic and ethnic background, but differing organisationally or environmentally, e. g., traditional/rural vs. modernist/urban communities in Ireland (cf. Kallen 2005), or between people with radically different national and/or ethnic origins; the latter tradition of work is represented here by Nakane; Spencer-Oatey and Jianyu Xing.

However, as Nakane points out, simple, deterministic views of certain participants as behaving 'differently' due to their ethnic or national background may be misleading. She challenges the commonly held view that, overall, Japanese communicators are more silent than their 'western' counterparts or, in her study, Anglo-Australian speakers. Nakane demonstrates how Japanese students' decision to remain silent in a tutorial may in fact be attributed to a combination of possible cognitive, interactional (sequential) and locally strategic reasons, rather than simply to their ethnic/national background.

It is also necessary to emphasise the role of interpersonal power in the use and interpretation of silence. As noted by Braithwaite (1990), one of the features of silence is that it frequently occurs in situations marked for a significant power differential between participants. Indeed, a number of studies in this issue discuss silence as a means of exerting influence, control and dominance (O Malley; Julé; Galasiński and Galasińska). Interestingly, much of such controlling work in relation to silence, and language in general, is done through metapragmatic comments about one's own and others' uses of silence, and metapragmatic data is used across different articles here, too (Cotterill; Spencer-Oatey 
and Jianyu Xing; Nakane), bringing home the common observation that language ideology resides at the meta-level of language interpretation, commentary and debate (cf. Schieffelin et al. 1998; Blommaert 1999; Jaworski et al. 2004). The use of metapragmatic data for the study of silence can also be crucial for identifying instances of silence which otherwise might have escaped our attention undetected due to a lack of a significant linguistic reflex (cf. Linde 2001 on accessing stories that are not told).

One of the telling indications that our overt interpretations of silence are strategic and power-based is Cotterill's finding that, in her data, trial judges usually resort to the interpretation of the accused/defendant's silence to their detriment (e. g., as an expression or corroboration of guilt). However, alternative interpretations of silence are accessible and open to judges, as indicated by one example quoted by Cotterill of a judge interpreting a defendant's silence with sympathy rather than resentment.

Related to these functions are motivations for silence. Not all silence is meant to be meaningful or communicative (Cotterill; Spencer-Oatey and Jianyu Xing), but not all silence that is communicative comes from the same source. Following Kurzon (1995), for example, Cotterill mentions 'unintentional' and 'intentional' silences, which, simplifying matters here, may arise out of one's inability to talk and one's unwillingness to talk, respectively. In a similar vein, Jaworski et al. deal with a news station's silence conceived of as an inability to report new news due to lack of knowledge of what goes on. Some individuals or groups (e. g., women) may be denied the 'linguistic space' in which to talk (Julé). Others may choose to remain silent about what is taken for granted in order to maintain the status quo (O Malley) or for positive self-presentation (Galasiński and Galasińska); silence may be used to save face in case of ignorance about an issue (Nakane), and even to facilitate understanding by slowing down one's tempo of speech and increasing the length of pauses as part of one's foreigner talk (Spencer-Oatey and Jianyu Xing).

Just as the papers gathered here attest to a variety of meanings and functions of silence, they also demonstrate - and not for the first time that silence has many forms and can appear in different interpretative guises: intra-turn and inter-turn acoustic pauses, non-talk, 'uncomfortable' silences (Nakane; Spencer-Oatey and Jianyu Xing), failure to say what may be expected, exercising the right to silence (Cotterill), covert denial of the right to talk (Julé), leaving something unsaid (O Malley; Galasiński and Galasińska), filled pauses, hesitation, repetition, irrelevant talk (Jaworski et al.). The latter paper also refers to multimodal aspects of silence using it as a metaphor in relation to the informational void of the TV screen in the case of random, unscripted, blank, or 'back- 
stage' shots, instead of, or while waiting for the expected news footage. And, in the same study, we find exemplification of yet another form of silence, that contrasting with the absence of non-linguistic sound or noise, as used in a soundtrack of news video footage.

Leaving the reader with this collection, I would like to thank all the authors for their contributions to this special issue. Clare MacMartin and Curtis LeBaron, and Anne L. Lawrie presented papers at the ICLASP 8 Symposium, but were unable to contribute to this publication. Sik Hung $\mathrm{Ng}$ and other colleagues at City University of Hong Kong are to be thanked for their efficiency and kindness with which the conference was organised and run. Last but not least, I am grateful to Dick Watts for his support for this project, allowing us to use Multilingua as a platform to present our work, and for his editorial assistance in the final stages of its preparation.

Cardiff University

\section{References}

Blommaert, Jan (ed.) (1999). Language Ideological Debates. Berlin: Mouton de Gruyter.

Braithwaite, Charles A. (1990). Communicative silence: A cross-cultural study of Basso's hypothesis. In Carbaugh, Donal (ed.), Cultural Communication and Intercultural Contact. Hillsdale, N.J.: Lawrence Erlbaum, 321-327.

Cacoullos, Ann R. and Maria Sifianou (eds.) (1998). Anatomies of Silence. Athens: University of Athens.

Drew, Paul and John Heritage (1992). Analyzing talk at work: An introduction. In Drew, Paul and John Heritage (eds.), Talk at Work: Interaction in Institutional Settings. Cambridge: Cambridge University Press, 3-65.

Granger, Colette A. (2004). Silence in Second Language Acquisition. Clevedon: Multilingual Matters.

Guerrero, Laura K., Joseph A. DeVito and Michael Hecht (eds.) (1999). The Nonverbal Communication Reader. $2^{\text {nd }}$ edition. Prospect Heights, Ill.: Waveland Press.

Huckin, Thomas N. (2002). Textual silence and the discourse of homelessness. Discourse and Society 13, 347-372.

Jaworski, Adam (1993). The Power of Silence: Social and Pragmatic Perspectives. Newbury Park, CA.: Sage.

Jaworski, Adam (ed.) (1997). Silence: Interdisciplinary Perspectives. Berlin: Mouton de Gruyter.

Jaworski, Adam, Nikolas Coupland and Dariusz Galasiński (eds.) (2004). Metalanguage: Social and Ideological Perspectives. Berlin: Mouton de Gruyter.

Johnstone, Barbara (2002). Discourse Analysis. Oxford: Blackwell Publishers.

Julé, Allyson (2004). Gender, Participation and Silence in the Language Classroom: Sh-shushing the Girls. Basingstoke: Palgrave Macmillan.

Kallen, Jeffrey L. (2005). Silence and mitigation in Irish English discourse. In Klaus Schneider and Anne Barron (eds.), Variational Pragmatics: The Case of English in Ireland. Berlin: Mouton de Gruyter.

Kurzon, Dennis (1995). The right of silence: A socio-pragmatic model of interpretation. Journal of Pragmatics 23, 55-69. 


\section{Adam Jaworski}

- (1997). Discourse of Silence. Amsterdam/Philadelphia: John Benjamins.

Leander, Kevin M. (2002). Silencing in classroom Interaction: Producing and relating social spaces. Discourse Processes 34, 193-235.

Levinson, Stephen C. (1992). Activity types and language. In Drew, Paul and John Heritage (eds.), Talk at Work: Interaction in Institutional Settings. Cambridge: Cambridge University Press, 66-100.

Linde, Charlotte (2001). Narrative in institutions. In Schiffrin, Deborah, Deborah Tannen and Heidi E. Hamilton (eds.), The Handbook of Discourse Analysis. Oxford: Blackwell Publishing, 518-535.

Mesthrie, Rajend, Joan Swann, Andrea Deumert and William L. Leap (2000). Introducing Sociolinguistics. Edinburgh: Edinburgh University Press.

Ng, Sik Hung, Christopher N. Candlin and Chi Yue Chiu (eds.) (2004). Language Matters: Communication, Identity, and Culture. Hong Kong: City University of Hong Kong Press.

Saville-Troike, Muriel (1985). The place of silence in an integrated theory of communication. In Tannen, Deborah and Muriel Saville-Troike (eds.), Perspectives on Silence. Norwood, N.J.: Ablex, 3-18.

Schieffelin, Bambi B., Kathryn A. Woolard and Paul V. Kroskrity (eds.) (1998). Language Ideologies: Practice and Theory. New York: Oxford University Press.

Scollon, Ron and Suzanne Wong Scollon (1995). Intercultural Communication. Oxford: Blackwell.

Tannen, Deborah (1985). Silence: Anything but. In Tannen, Deborah and Muriel Saville-Troike (eds.), Perspectives on Silence. Norwood, N.J.: Ablex, 93-111.

Tannen, Deborah and Muriel Saville-Troike (eds.) (1985). Perspectives on Silence. Norwood, N.J.: Ablex.

Thiesmeyer, Lynn (ed.) (2003). Discourse and Silencing: Representation and the Language of Displacement. Amsterdam/Philadelphia: John Benjamins. 